\title{
Women as Tireless Goddesses, Super-Humans and Geniuses in the African Alternative Cinema
}

\section{Lawrence Ekwok}

Department of Theatre and Media Studies, University of Calabar, Calabar, Nigeria

Email address:

Merlaw2002@yahoo.com

\section{To cite this article:}

Lawrence Ekwok. Women as Tireless Goddesses, Super-Humans and Geniuses in the African Alternative Cinema. International Journal of Information and Communication Sciences. Vol. 2, No. 5, 2017, pp. 68-74. doi: 10.11648/j.ijics.20170205.13

Received: April 10, 2017; Accepted: May 13, 2017; Published: October 24, 2017

\begin{abstract}
Given male domination of the cinema medium, women portrayal in films has dominantly been stereotypical. This trend has been observed even in the African cinema. To counter this trend, a number of theorists and feminist schools of thought have proffered the African alternative cinema movement which insists on women writing their story by themselves so as to correct patriarchal portrayals of women in films. This paper seeks to critically examine this movement with respect to realism. Based on observation and a critical analysis of some Ghanaian and Nollywood films directed by females, it argues that the alternative African cinema may orchestrate a portrayal of women which is more utopian than realistic. Though having the potential to pertinently question the status quo - which is still highly detrimental to women - such a cinematic movement may somehow depart from factual or empirical reality about African women to rather construct and sell a dreamed - but unrealistic - image of the African woman.
\end{abstract}

Keywords: Alternative Cinema, Realism, Utopianism, Femme Fatale, Femininity, Patriarchy

\section{Introduction}

Cinematic representations of women have mostly been critiqued and censured by feminist film theorists and audiences on the grounds of chauvinism, misogyny and bigotry. This is not unconnected to the fact that such filmic representations generally denigrate, debase and objectify women, relegating them to the status of second class citizens and sex objects meant to satisfy masculine desires, as well as persons who are vulnerable and highly dependent on the men fold for achievement in life. Most representations of women in films give (keen) spectatorship the impression that women are totally incapacitated - that they are naturally 'sterile' and impotent - unless they enjoy the assistance of the men fold. Such cinematic representations seem to exclude women from positions of greatness. One may illustrate this observation by the fact that women are hardly given lead or protagonist roles in mainstream cinema. They are mostly presented as the spectacle and hardly assume the position of the spectator.

According to a recent study carried out by the Centre for the Study of Women in Television and Film (CSWTF), female actors represent only $12 \%$ of the protagonists in topgrossing Hollywood films in 2014. They are under- represented - nay unrepresented - even in secondary roles, as they comprise barely $29 \%$ of major character and $30 \%$ of the totality of speaking characters [1]. And according to Lang, such percentages are likely to decrease over the years [2]. The CSWTF is therefore perfectly right to call the cinematic industry "a man's (celluloid) world" [1]. Male literal domination of the film industry can further be vividly illustrated by the chronic under/mis- representation of women and the prevalence of negative stereotypes against the women folk in most, if not all cinematic industries in the world. With particular reference to the Hollywood industry (third largest film industry of the world), Lauzen Martha (the executive director of the Center for the Study of Women in Television and Film) succinctly notes that "the chronic under-representation of girls and women reveals a kind of arrested development in the mainstream film industry" [1]. She further deplores the fact that few exceptions of films with feminine characters as lead roles may fool the public opinion. However, the stalking reality remains: the cinema industry is indisputably a male world and a site of chauvinistic expression. As She pointedly concedes, "there is a growing disconnect or gap between what we might perceive as being the current status of women in film and 
their actual status, [...] A few high-profile cases can skew our thinking" [1].

Though it may be hard to find reliable statistics to mathematically describe women's representation in African cinema, it has generally been assumed or guessed that the situation is worst in Africa, compared to other continents. At least, numerous empirical studies have demonstrated the persistence of negative stereotyping of women in the various African films [3-9]. In view of this technical and structural anomaly, feminist critics and female African film critics have since advocated the emergence of a feminine alternative cinema which, being feminist/womanist in inclination, will labour to correct the chauvinistic representation of women in the male dominated (mainstream) African cinema. As Okunna succinctly puts it, the need for an 'alternative video' is really urgent in Africa. Such alternative cinema represents the "best strategy, if not the only one", at this phase of our development in Africa in general and Nigeria in particular, "to empower women through this medium of communication - by getting them [the African women] to tell their story from their own perspective" [10, p. 35].

The alternative cinema movement thus longs to reverse or correct the ugly situation, marked by misrepresentation of women in African cinema. This, of course, entails the creation of women characters that will honour feminine dignity and emphasize humanity in women. In line with this, it is generally assumed that women representation in the alternative cinema will radically depart from the objectifying and "abjectifying" portrayals of women in the male dominated cinema; to paint women in a mostly positive light - say as "angels", "super-humans", "geniuses", in short, women with super and astonishing qualities. It is also envisaged that such an alternative orientation by women or feminist filmmakers will integrate the attribution of protagonist roles to women, perhaps more than to men. Though pertinent, the alternative (women) cinema poses a serious problematic which borders on the two binary opposites of realism and utopia.

This paper seeks to critically examine the movement with respect to realism. It argues that the alternative African cinema may orchestrate a portrayal of women which is more utopian than realistic. Though having the potential to pertinently question the status quo - which is still highly detrimental to women - such a cinematic movement may somehow depart from factual or empirical reality about African women to rather construct and sell a dreamed - but unrealistic - image of the African woman.

\section{Conceptual and Theoretical Issues}

This section provides a conceptual framework giving attention to the three terms of alternative (African) cinema, realism and utopia. The term alternative cinema has been used by a number of critics and film theorists (within the context of women studies) to describe neo cinematic traditions that may remarkably depart from the male dominated cinema which seems principally calibrated to debase, misrepresent, marginalize and objectify women. In her definition of the concept, Okunna reveals that the alternative cinema idiom could be deployed to name a movement which is bent on empowering women through the instrumentality of the cinematic medium [10]. Such an empowerment hinges on enabling women to tell their story from their own angle. The alternative cinema paradigm seeks to orchestrate a more homogeneous and balance view of the Black continent and of the African women universe through the wisdom of giving a cinematic voice to about fifty percent of the continent population (African women). This conception of alternative cinema rests so much on the popular belief among feminist critics that the negative portrayal of women in cinema is one of the biter fruits of the underrepresentation of women at all levels of the film and other media industries. It is, in effect, estimated by Bird Eye View that women constitute less than $10 \%$ of film directors and $15 \%$ screen writers internationally. Such a representation may even be reduced in the African context [6, p. 21].

In view of all the above mentioned facts, it is widely believed that if women representation is positively revised at the various stages of film production (notably scripting, film directing, screen writing and acting among others), their portrayal will drastically be ameliorated. Badoe, Mama \& Mekuria vividly echo this myth when they concede that a growing population of feminist or womanist women at the levels of film-making, screen-writing, production, image picking, light and sound expertise and editing "is the surest answer to the challenges of changing the limited and distorted representations of African women that have held sway since the earliest colonial propaganda films, and of developing a cinematic language attuned to the lived realities of African people" [11]. Diawara takes the reflexion farther as she advocates the application of women affirmative policies in the different African cinemas. She pointedly underscores the fact that the presence of women on the scene is indispensable for African cinema - the same as African political leadership - to hope to prosper [12]. Though high calibre male filmmakers such as Sembene and Cissoko have, through their filmic productions, demonstrated that men of the African film industry could be feminist in inclination, their cinematic efforts "will not be satisfactory. [...] until we have affirmative action in Africa to include women in politics, in classrooms, in film schools, and in every other sector of life" [12, p. 161].

Badoe et al [11] and Diawara [12] cited above indirectly underscore a very important characteristic of the alternative cinema current: the feminist inclination of the (women) filmmakers. This emphasis is cardinal in the sense that, the sex of African filmmakers has not always determined the level of gender sensitivity of their film contents. While a number of male African filmmakers (particularly postcolonial film directors - such as Sembene Ousmane through his films Borom (1963), Black Girl (1966), Emitai (1971), Ceddo (1972), Moolaadé (2004) and Cheik Oumar Cissoko with his film Finzan (1992) - have sometimes manifested a feminist inclination, there have been replete 
instances of negative portrayals of the women folk in the filmic productions of female directors. A case in point is a number of films by Nigerian female director Helen Ukpabio namely, Revelation (2003) and The Price (2004), in which there is a great deal of negative female characterisation. In these films, women are mostly presented as frivolous prostitutes, wayward nymphs and sex objects. Another egregious example is Judith Mazagwu's Destructive Instinct $1,2,3$ and 4 which contain serious pornographic contents and in which women are variously objectified. It therefore goes without saying that numerous female film directors, screenwriters, actors and makers seem to have internalized the dominant chauvinistic dogmas which tend to guide or drive cinematic traditions in mainstream cinema. This makes them to likely be chauvinistic in their cinematic expression/production. This notwithstanding the African women film movement postulates that women stories are better written and told by themselves. Tari pungently corroborates this position in her collection of the following quotes:

It is better to know yourself than for someone to tell you who you are. Identity often comes down to the meanings that are attached to bodies when they are rendered as objects of vision [...] vision and the visual are tools of social ordering. [...] the body, as we well know, is never simply matter, for it is never divorced from perception and interpretation. [9, p. 7]

In guise of recapitulation, the alternative cinema (in the African perspective), is a movement which mainly engulfs female - but occasionally male - African filmmakers, who, being feminist or womanist in orientation seek to empower the women folk through a cinematic production which drastically departs from the orthodox/chauvinistic representation of women in mainstream media. Another name often used to refer to this alternative cinema is "African Women Cinema Movement" (which however is cinema exclusively by African women). The movement is evidenced by a number of factors which point to increased attention to a feminine expertise and affirmative action in cinematic production. Some of these factors include the increasing interest of film distributors to acquired films directed by African women directors; the creation of African women film category in reputed film festivals and conferences as well as the attention given to African women in film studies by the syllabi and curriculums of numerous universities in and outside the African continent $[4,6,11]$.

It is however important here to underscore the existence of two currents within the alternative African women cinema movement. The first which is visibly modest, moderate and realistic, do not actually advocate a diametrical reversal of male gaze and female spectacle phenomenon in mainstream cinema through unmeasured or boundless homage to the black women [6]. This brand of proponents of the movement prefers to simply digress from major tropes of the African cinemas. As female film director Teddy Mattera succinctly contends, "We have been the object of the gaze. We don't want to return the gaze, we want to look elsewhere" [6]. Understanding the difficulty nay impossibility to objectively characterize what may be referred to as a positive depiction of women in cinema, the moderate alternative cinema current simply advocates the development of a "neutral" gaze or non-gendered look by women filmmakers. The second brand of apologists of the alternative model of African cinema is rather radical and somehow visionary as it advocates a portrayal of the African in a relatively glamorous light, visibly irrespective of the social reality. Such a current advocates that women numerically dominate in terms of of titular characters in films and that they be depicted as vaunted heroines and tireless goddesses among others. Leal somehow endorses this conception in her description of the role of female filmmakers. She advocates that women be viewed and portrayed in films as being part of the movement of Afropolitanism, a neologism coined by Cameroonian philosopher Achille Mbembe to inaugurate an idealistic African civil society purified of all forms of essentialism, masked inferiorities and patron-client vassalage and where the artist goes hand-in-hand with the statesman [13-14].

This section of the essay equally gives attention to the two concepts of realism and utopia mainly with respect to cinema. Realism as a philosophy in cinematic production has mainly been concerned with depicting the actual world as it is. Proponents of this current seek not necessarily to show the actual world but to construct their films in a way that it will look like the real world. The school of thought is believed to have started with the Lumière Brothers before taking a greater dimension during WW II period in Italy with neorealist proponents such as Gianetti who introduced the dictum that "if it's too pretty, it's false" [15]. In line with this, neo-realist filmmakers based their production on the maxim that the more a film is embellished (with special effects and other forms of artifices) the more it is unrealistic. They therefore mostly explored social issues in their plot construction; mostly employed unprofessional actors who acted their real selves and generally did not build/engineer their setting. To this above mentioned tenets of realism, Mckibbin adds a non-exhaustive list of other characteristics (of realism). He notes "the absence of non-diegetic music, the use of off-screen sound, the prevalence of an nonobstructive, under-privileged sense of framing, the use of colloquial dialogue (which most often are half-heard) against the light camera work, monochrome or muted colour photography, and the sense that if there is a plot, it comes out of the immediacy of a life: that is it naturally depicts a social problem rather than providing an escape from it [16].

With close reference to Victorio's Bicycles Theives and De Sica's Umberto D, Bazin gives a good description of the neorealist movement indirectly stressing how the current differs from other cinema currents. He notes that in neo-realistic films, "the narrative unit is not the episode, the event, the sudden turn of events, or the character of its protagonists; it is the succession of concrete instants of life, no one of which can be said to be more important, for their ontological equality destroys drama at its very basis" [15]. This observation emphasizes the neo-realists' belief in a filmmaking process which is stripped of - or "purified" from 
- excessive made beliefs, and which is bent on underscoring contemplation, the respect of the life in which the filmmakers lived in rather than the mechanization of plots.

Today's conceptions of film realism somehow differ from Bazin's observation. In effect, realism in filmic text is today judged in function with the natural laws, the general social condition and more curiously the possibilities of real life. This means that realism is not just about showing the actual world as it is, but showing how it could be, provided the filmmaker's imagination does not extrapolate the limits of the natural and the possible. In his book titled, Media Unlimited: How the Torrent of Images and sounds Overwhelms Our Lives, Todd insightfully stresses this axiom $[17$, p. 22]. He notes that cinematic images vividly re-present or depict realities though they are not themselves realities and audiences intuitively know or understand this. When an image depicts an experience familiar to the audience, something that once happened to them or something they can image happening, they consider it realistic even though "that is still not real". As he further contends, "despite the fact that audiences know these [cinematic] images are 'almost real', they expect them to heighten life, to intensify and focus it by being better than the real, more vivid, more stark, more something. We want a burst of feeling, a frisson or commiseration, a flash of delight, a moment of recognition" [17, p. 23].

Realism is judged more from the audience's point of view (or standard) than from the filmmakers' point of view. This is so as there is possibility that a filmmaker believes in something the audiences consider unrealistic or fabulous. There are even more complicated and ambiguous contexts in which the filmmaker's intention or vision is totally indiscernible by the audiences. In some other situations the filmmakers completely or partially has his/her facts wrong. S/he presents a more or less unintentionally distorted reality which, of course, is his/her (version of) reality and not that of the audience. However, according to Korman, a film director, scriptwriter or producer may have his facts correct but the way s/he slants them and deploys other relevant tools of cinematic production, may end up orchestrating a distortion of reality [18, $p .117]$. He enthuses that:

Accuracy is not always the problem [when it comes to emphasising realism in a cinematic text]; it is the interpretation of the accurate facts that must be considered. The relationship between facts and their portrayal varies greatly according to, not only the writing and directing of a film, but aspects of production value (such as budget, star power and cinematography).

Utopia on the other hand is simplistically envisaged as a derivative of the term utopianism. It is deployed in reference to the dreams and nightmares which drive socio-political action. A utopia is generally viewed as a positive manifestation of utopianism, the negative type being dystopia. Utopias stem from discontentment with the present situation and always identify specific issues or situations (generally anomia or dysnomia in their authors' worlds) which imperatively need to be corrected. Some equally formulate eutopian visions, "daring" and revolutionary socio-political experiments among which feminism or womanism can be mentioned. Political analysts regard utopias as being profoundly political and as revolving around themes like methods of administration, gender relations, and ownership of propriety in a specific place [19]. They (utopias) profoundly analyse the present situation in a society to propose vision of better ways to structure/organise human existence. They formulate the revolutionary world views of their authors who usually desire the transformation of society through the introduction of new ideas. Generally, utopias are or represent the idea of a perfect world where everybody is gratified according to his/her desires and where no one has unsatisfied expectations. Their political functions therefore include the criticism of the present and the imagination of alternative - often radical - ways. Having the potentials to be heuristic, catalytic and didactic, utopia may be expressed in a variety of experiences or discourses including science fiction (cinema in general), popular music, social and political theory, architecture and medicine among others.

Utopia is often relegated by realist or pragmatist critics to the conception of unattainable ideals. Such critics equally censure utopianism on the ground that it supports the idea of a dream world and proposes merely intangible frameworks. The inherent intangibility of utopias is often source of misapplication of national policies [19-21]. In tandem with this, Sclark doubts the possibility for utopias to enjoy a universal appeal, thereby underscoring the unavoidability of the generation of concurrent utopias on a same issue. Sclark succinctly notes that:

The myth of a Utopia and the practical application of one not only are very different, but rather they directly stand opposed to one another because Utopian ideals are unattainable, and in order to overcome this inherent intangibility they push their governments to act in immoral ways, and the immoral acts of the government breed the end to the Utopia, in its purest form. [22]

Though Sclark sometimes proffers the use of the "coinage utopian idealism", some political theorists think utopianism ought to be differentiated from idealism. While idealists always appear to constitute a kind of conservative thinkers who profoundly dread the deterioration of the world if new and untested ideas are introduced, the utopians on the other hand want to transform the world into a wonderful place through breakthroughs and revolutionary innovations. Utopians therefore consider idealists - in most instances - to be a barrier to positive change.

\section{Alternative Feminist Cinema and Realism}

Partisans of the alternative cinema often attack chauvinistic films (authored by male) on the ground of unrealism or unauthentic framing. The general tendency by these feminist critics has been to view male-authored filmic scripts as carriers or conveyors of a partial truth, "a half 
story", as Adichie (cited in Endong) and some other observers will pungently put it. This partial truth is believed to be the predictable product of the fact that, chauvinistic films overemphasise negativism in the Black African women's image, glaringly overlooking African women's potentials to contribute to the socio-political and economic development of black communities [23-24]. Okunna succinctly illustrates this feminist frame of mind when she opines that there must be African women who are as depraved and deplorable as the negative female characters deployed in the male-authored sexist films. However, "evil women like negative news in the mass media generally, are 'over-reported' in these films" [10, p. 31]. By over-reporting - if not exclusively reporting - the negative aspects of African women's identities, these films systematically sideline and downplay the efforts presently made by women to engender or sustain development in many African communities. As Okunna further observes, women have since been working hard for the growth of their families and communities. These are welcomed mutations that should attract the attention of film directors. In concrete terms, such wonderful feminine efforts should be lauded in feminine/feminist film production to ultimately balance the portrayal of Black African women in the cinema medium and secure a more heterogeneous view of the African woman [10]. Such a paradigm (African women cinema movement) stands the chance to change the limited and subtly distorted representations of the African women that have held sway since the colonial period.

For the sake of realism therefore, it will be imperative, according to most adepts of the alternative cinema movement, to present the other part of the truth, what Dovey calls "the other half of the story". According to the moderate wing of the alternative cinema movement, this other half of the story should strictly avoid clear "vindictive" exaggerations that will systematically attempt to aggressively be corrective of chauvinistic representations of women in the mainstream male dominated cinema. As has been recommended by various apostles of the current, African women cinema movement should avoid "returning the gaze" - that is, imitating the male chauvinistic films in a vindictive manner. Instead, they should look somewhere else. This entails developing a cinematic language which is essentially attuned to the lived realities of the entire African people, irrespective of gender. This will also entail paying serious attention to socio-cultural differences between the Western woman, African women of the Diaspora and pure African women. As cinema guru Aminata Oudraogo clearly puts it, "women of the Diaspora and African women do not live the same reality. Our problems are similar but are not posed in the same way. [...] We asked the women of the African Diaspora to let us first talk among ourselves before meeting them" $[11$, p. 6].

The above recommendation is more than pertinent as we know that social realities in the west are not - and may never - be the same as in Africa. Though there have been continuous passions by African women to willingly or accidentally copy western behavioural models and feminist positions, the Black African women will always somehow differ from the western, radically feminist women. The fact that even the feminist current is presently having cultural accents (evidenced by African feminists' creation of neologisms such woomanism, no-ego feminism - which support the idea that women should abstain from seeing man as the other, but as the essential other half to any conceptualization of what it means to be a human being) is already edifying to the need to always portray the African woman according to socio-cultural realities. In line with this, Owusu argues that producing 'positive images' as desired portraits of African women by women should take into account socio-cultural ideologies, realistic and progressive modes of representation as they relate to the African experience [5].

Based on all these premises, the act of transposing the western woman situation in a film meant to depict the African woman may be read as unrealistic or inauthentic and a form of cultural synchronization; even if such a cinematic choice is originally aimed at correcting the stereotypical representations of women by male-authored films [5, 3]. Tari shares corollaries as she enthuses that, alternative female African filmmakers should thrive towards achieving a "middle ground" where the women will neither be preys for men nor predators. She remarks that:

Shunning the victim narrative and embracing the equally hegemonic societally imposed ideology of the femme fatale does not 'do justice' to the everyday [African] woman. There has to be a point, a middle ground of sorts, where I as a woman - Nigerian, African, or otherwise - am neither victim nor aggressor. At some point, I must simply be 'woman', defined and preceded not by my sexuality, but by the nature of my humanity. [9]

In view of this, Leal notes that recent African cinematic production by women directors have mainly avoided to present their female characters as "vaunted heroine or timeless goddess"; but as brave feminists who transgress social conventions, abandoning their abusive husbands [14]. In effect, the image of a relatively independent woman ready to surmount social gender unfriendly fixations to be outstanding in African society has been characteristic of a growing tendency to present the conflicts faced by contemporary African women in a fictional idiom.

\section{Alternative Cinema as Utopia}

A good number of African female filmmakers - the same as their writer sisters - have displayed radical feminist inclinations (western feminist ideologies) in their films. Such inclinations have often predisposed them to construct a film scripts which, though corrective of the negative stereotyping of Black African women, are deeply rooted in utopianism and idealism. Owusu shares corollaries in her study of Frimpong-Manso's Scorned. She observes that FrimpongManso's Scorned totally challenges Africans' notion of the battered women's none existing right to freedom [5]. The 
film equally releases the protagonist into the mode of defiance and justice which renders her actions fantastic, fascinating but highly utopian. Through a survey of Ghanaian women's perception of the film, Owusu gets more interesting findings, pointing to the utopian nature of the film. She writes that:

The women respondents who took part in the study [...] saw the actions of the female protagonist in Scorned as uncharacteristic of the Ghanaian woman she was supposed to represent. This was not to imply the respondents were happy with the image of the battered woman or the violence against her, but they were discontent with the manner in which her freedom was appropriated. [5]

As illustrated in Frimpong-Manso's films, female cineaste sometimes, assume the function of women empowerment advocates and agents of feminist revolution. They hope to question patriarchal strictures prevailing in African sociocultural spheres and sensitize women on the need to stand for their rights or to be further emancipated from masculine domination. As shown in the above mentioned quotation, the tendency of using a radical feminist orientation in depicting womanhood in African movies often conflicts with African audiences' reading or reception of the films. When African woman are depicted as "femme fatale" or entities that have immense power to subvert men, the aspect of realism often seem absent. Audiences rarely square their experiences with such radical feminist claims in the filmic text. It may therefore be expedient, for adept of the alternative feminine cinema to consider Tari's recommendation that: "shunning the victim narrative and embracing the equally hegemonic societally imposed ideology of the femme fatale does not 'do justice' to the everyday [African] woman" [9]. In other words, it does not give an authentic image of the African woman - not only the traditionally African woman but even the modern one. Feminist writer Calyxte Beyala share corollaries as she underscores the difference between the modern African woman (who is feminist) and her western counterpart. She notes that « in the west, feminism has deviated into a kind of 'machinism' where western women are trying to kill their femininity. Everything is done by feminist women to resemble men, as seen in women's assumption of masculine power. I do not support this philosophy" [25].

\section{Conclusion}

The Alternative (feminist) African cinema is a laudable paradigm as it creates an opportunity to question or challenge the dominantly patriarchal narrative which characterizes the present African cinema. This is so as it permits women to write their story and eventually influence societal perceptions of womanhood in African communities. It equally has the potential to serve as a strategic tool for women empowerment and women affirmative action in the African continent. However, this movement may be regarded as somehow problematic when it directly or indirectly advocates the adoption by African women of a western identity. As shown with Ghanaian audiences' reception of Frimpong-Manso's
Scorned, exaggerated or excessive feminist inclination by female African directors - through depiction of African women as "femme fatale", super-human or entities which assume masculine power - may instead be viewed as unrealistic. This tends to be in line with the theory that stipulates that, if not well "regulated", the alternative feminine cinema may instead advocate a portrayal of women which is more utopian than realistic.

\section{References}

[1] Center for the Study of Women in Television and Film (2014). It is a Man's (Celluloid) World. San Diego: Center for the Study of Women in Television and Film.

[2] Lang, Brent (2015). Study Finds Fewer Lead roles for Women in Hollywood. Vareity, available [online] at http://variety.com/2015/film/news/women-lead-roles-inmovies-study-hunger-games-gone-girl-1201429016/ Accessed on the $30 / 04 / 2016$.

[3] Endong, Floribert P. C. (2017). The Female Media Producer as an Advocate of Women Empowerment in Nigeria: The Cross River Experience. Gender Studies, 7 (1), 168-183.

[4] Ellerson, Beti (2004). Visualising Herstories: Towards an Introduction to African Cinema Studies. Retrieved June 10, 2016, from http:www.visualising-herstories.htm.

[5] Owusu, Osei Joyce (2011). Researching Ghanaian Women in Cinema. African Women in Cinema Blog. Retrieved June 10, 2016, from

http://africanwomenincinema.blogspot.com.ng/2011/08/joyceosei-owusu-researching-ghanaian.html.

[6] Dovey, Lindiwe (2014). New Looks: The Rise of African Women Filmmakers. Feminist Africa, 16, 18-38.

[7] Shaka, Femi Okiremuette \& Uchendu, Ola Nnennaya (2012). Gender Representation in Nollywood Video Film Culture. The Grab: Journal of Theatre and Media Arts, 7, 1- 30.

[8] Agbese, Aje-Ori (2012). Setting the Agenda for Women's Liberation and Empowerment in Nigeria through Movies: An Analysis of Women's Cot, Woman in Power and The Bank Manager. SMC: Journal of Cultural and Media Studies, 2 (1), 73-100.

[9] Tari, Sikoki (2014). Shedding Light on the Dark. Interrogating Representations of Africa and Its Women. Female Artists' Exhibition and Workshop. Deconstructing the Politics of Sexuality, (pp. 7-15), Lagos: Female Artist Foundations.

[10] Okunna, Chinyere Stella (1996). Portrayal of Women in Nigerian Home Video Films: Empowerment or Subjugation? African Media Review, 10 (3), 21-36.

[11] Badoe, Yaba; Mama, Amina \& Mekuria (2014). Editorial: African Feminist Engagements with Film. Feminist Africa, 16, $1-7$.

[12] Diawara, Manthia (2010). New Forms of Aesthetics and Politics. Munich, Berlin, London and New York: Prestel.

[13] Mbembe, Achille (2000). De la Poscolonie: Essai sur l'Imagibation Politique dans l'Afrique Contemporaire. Paris: Karthala. 
[14] Leal, Riesco Beatriz (2013). The Woman in Contemporary African Cinema: Protagonism and Representation, BUALA, Available [online] at http://www.the-woman-incontemporary-african-cinema-protagonism-andrepresentation_BUALA.htm Accessed on 04/05/2016.

[15] Bazin, Andre (2003). "The Myth of Total Cinema". In A. Bazin (Ed), What is Cinema? California: California University Press, 234-239.

[16] Mckibbin, Tony (2015). Cinema Reality. Available [online] at http://www.tonymckibbin.com Accessed on the 4/05/206.

[17] Todd, Gitlin (2001). Media Unlimited: How the Torrent of Images and Sounds Overwhelms Our Lives, New York: Palgrave.

[18] Korman, Becky (2007). "African" Cinema: A Comparative Look at Blood Diamond and Ezra. OFF SCREEN: The Experience of Cinema, 11 (6), 117-136.

[19] Sagisson, Lucy and Burns, Tony (2015). Research: Utopianism, Realism and Ideal Theory. Concept. Available [online] at

http://www.nottingham.ac.uk/concept/research/utopianismreal ismidealtheory.aspx Accessed on 4/05/2016.

[20] Sabrina, Mach and James, Page (2009). Utopians and Idealists: Who Can Handle Innovations? Johnny Holland Magazine, 17, 66-80.
[21] Smith, Anne Collins \& Smith, Owen M. (2011). Pragmatism and Meaning: Assessing the Message of Star Trek: The Original Series. Participations: Journal of Audience and Reception Studies, 8 (2), 74-85.

[22] Saratu, Abiola (2016). Re-Imagining Ourselves: Music, Film and the Representation of Nigerian Women. Africa Speaks for Africa: Perspective from a Diverse Continent. Available [online] at http://africaspeaks4africa.org/re-imaginingourselves-music-film-and-the-representation-of-nigerianwomen/ Accessed on the 01/05/2016.

[23] Endong, Floribert Patrick C. (2017). Nollywood and the Nigerian Image Crisis. Journal of Globalization, 9 (1), 13 28.

[24] Emem-Obong, Inyang Lucia (2011). Promoting Women's Awareness Toward Change in Nigeria: The Role of Literature. MA Thesis presented to the School of Communication, Simon Fraser University.

[25] Hobson Janell (2015). Selma Shows Why we Need Moe Black Women Filmmakers. Ms. Magazine. Retrieved June 10, 2016, from http://africanwomenincinema.blogspot.com.ng/2011/08/joyceosei-owusu-researching-ghanaian.html. 